\title{
Article \\ Conventional and Enzyme-Assisted Extraction of Rosemary Leaves (Rosmarinus officinalis L.): Toward a Greener Approach to High Added-Value Extracts
}

\author{
Antonella Rozaria Nefeli Pontillo ${ }^{1}$, Lydia Papakosta-Tsigkri ${ }^{1}$, Theopisti Lymperopoulou ${ }^{2}$, Diomi Mamma ${ }^{3}$ (D), \\ Dimitris Kekos ${ }^{3}$ and Anastasia Detsi ${ }^{1, *(D)}$ \\ 1 Laboratory of Organic Chemistry, Zografou Campus, School of Chemical Engineering, \\ National Technical University of Athens, 15780 Athens, Greece; nefelipontillo@gmail.com (A.R.N.P.); \\ lydia.papacosta@gmail.com (L.P.-T.) \\ 2 Processes and Products Quality Control Horizontal Laboratory, Zografou Campus, \\ School of Chemical Engineering, National Technical University of Athens, 15780 Athens, Greece; \\ veralyb@chemeng.ntua.gr \\ 3 Biotechnology Laboratory, Zografou Campus, School of Chemical Engineering, \\ National Technical University of Athens, 15780 Athens, Greece; dmamma@chemeng.ntua.gr (D.M.); \\ kekos@chemeng.ntua.gr (D.K.) \\ * Correspondence: adetsi@chemeng.ntua.gr
}

\section{check for}

updates

Citation: Pontillo, A.R.N.; Papakosta-Tsigkri, L.;

Lymperopoulou, T.; Mamma, D.;

Kekos, D.; Detsi, A. Conventional and

Enzyme-Assisted Extraction of

Rosemary Leaves (Rosmarinus officinalis L.): Toward a Greener Approach to High Added-Value Extracts. Appl. Sci. 2021, 11, 3724 https://doi.org/10.3390/app11083724

Academic Editor: Simone Morais

Received: 21 March 2021

Accepted: 16 April 2021

Published: 20 April 2021

Publisher's Note: MDPI stays neutral with regard to jurisdictional claims in published maps and institutional affiliations.

Copyright: (c) 2021 by the authors. Licensee MDPI, Basel, Switzerland. This article is an open access article distributed under the terms and conditions of the Creative Commons Attribution (CC BY) license (https:// creativecommons.org/licenses/by/ $4.0 /)$
Abstract: The effect of different extraction methods of rosemary leaves on the total phenolic content (TPC), and the antioxidant activity of the extracts was herein investigated. Firstly, the solid-liquid conventional extraction (CEM) and microwave-assisted extraction (MAE) were implemented in an effort to identify the effect of the solvent and of microwave irradiation on the extract quality. The extract obtained from CEM at room temperature, using ethanol/water 95:5 $v / v$, showed the highest antioxidant activity $\left(\mathrm{IC}_{50}=12.1 \mu \mathrm{g} / \mathrm{mL}\right)$. MAE using ethanol/water 50:50 $\mathrm{v} / \mathrm{v}$ provided an extract with TPC and DPPH radical scavenging ability in a significantly shorter extraction time $(1 \mathrm{~h}$ for MAE and $24 \mathrm{~h}$ for CEM). Enzyme-assisted extraction (EAE) using five commercial enzyme formulations was implemented, and the kinetic equation was calculated. Finally, the effect of EAE as a pretreatment method to CEM was examined. Pretreatment of the plant material with pectinolytic enzymes for $1 \mathrm{~h}$ prior to a $24 \mathrm{~h}$ CEM with $50 \%$ hydroethanolic solvent was found to be the optimum conditions for the extraction of rosemary leaves, providing an extract with higher DPPH radical scavenging ability ( $\left.\mathrm{IC}_{50} 14.3 \pm 0.8 \mu \mathrm{g} / \mathrm{mL}\right)$ and TPC $\left(15.2 \pm 0.3 \mathrm{mg}_{\mathrm{GAE}} / \mathrm{g}_{\text {rosemary }}\right)$ than the corresponding extract without the enzyme pretreatment.

Keywords: rosemary leaves; enzyme-assisted extraction; antioxidant activity; total phenolic content

\section{Introduction}

Rosmarinus officinalis L., commonly known as rosemary, is a perennial herb, a member of the mint family Lamiaceae, native to the Mediterranean region. Rosemary extracts, as well as rosemary essential oil, are rich sources of phytochemicals and exhibit a wide range of bioactivity [1]. Rosemary leaf ethanolic extracts possess potent antioxidant and antimicrobial properties [2-4] and have found applications in food preservation. As part of the global interest in exploring natural products as pharmaceutical agents, the ability of rosemary extracts, as well as selected phytochemicals isolated from these extracts, to inhibit cancer cell proliferation has been studied in vitro on various cell lines as well as in vivo on animal models. The results confirm the promising anticancer and cytotoxic properties of rosemary extracts [5-7]. The wide therapeutic potential of rosemary extracts is complemented by potent anti-inflammatory and antidepressant activities [8,9].

The majority of studies on rosemary extraction refer to the ethanolic, hydroalcoholic, or aqueous extract obtained using conventional heating as well as high energy techniques 
(ultrasound- and microwave-assisted extractions) [1,10,11]. In order to increase the process yield as well as to optimize the bioactivity of rosemary extracts, a variety of pretreatment techniques performed on the plant material prior to extraction have been examined, such as deoiling, grinding, maceration, or pulsed electric fields (PEF) treatment [12,13]. Moreover, the ability of green solvents to extract bioactive phytochemicals from rosemary has attracted considerable attention recently. To cite the most recent examples, the group of Marfa et al. used choline chloride-based deep eutectic solvents to efficiently extract phenolics from rosemary leaves $[14,15]$. The deep eutectic solvents acted as protective agents for the extracted phytochemicals. Lefebvre et al. developed an on-line methodology combining supercritical $\mathrm{CO}_{2}$ extraction with supercritical chromatography [16] to achieve the sequential extraction of carnosic acid, rosmarinic acid, and pigments from rosemary leaves.

Enzyme-assisted extraction (EAE) is considered to be a promising, greener alternative to conventional extraction methods. Enzymes catalyze a variety of hydrolytic reactions acting on the existing polymers in the cell wall, such as pectin and hemicellulose. Bioactive components of the plants are usually linked to the cell wall polysaccharides either by hydrogen bonds or by being encapsulated in hydrophobic pockets, resulting in a stable complex. Hence, the enzyme-assisted extraction manages to release the phenolic compounds, rendering them more easily extractable, improving their extraction rate, selectivity, and yield. Moreover, the use of different enzymes, as well as different extraction conditions, strongly affects the outcome, enabling the development of a tailor-made extraction formula to obtain an added-value final product $[17,18]$.

Song et al. [19] studied the extraction of polysaccharides from the leaves of lotus with four different enzyme types, namely amylase, cellulose, protease, and pectinase. All extracts showed different chemical compositions with the use of pectinase, resulting in an extract with good immunostimulatory activity. Lombardelli et al. [20] were able, via experimental design and statistical analysis, to determine the optimal conditions of the combined use of polygalacturonase, pectin lyase, cellulose, xylanase for the extraction of carotenoids from tomatoes. It was proved that the experimental conditions play a vital role in the properties of the extract obtained. Neta et al. [21] investigated the optimization of the conditions for the recovery of bioactive compounds from lentils with the use of proteases and cellulases. The results of the study revealed an up to $226 \%$ improvement of the antioxidant activity of the extract, compared to a non-enzymatic extraction technique. Recently, Nguyen et al. [22] reported an enzymatic approach for the extraction of rosemary leaves which was implemented using Cellulase A and four proteases. The results obtained from the experimental design revealed that the highest rosmarinic acid extraction was achieved after $4.6 \mathrm{~h}$ of extraction at $36.6{ }^{\circ} \mathrm{C}$ using Cellulase A at concentration $2.56 \%$ and a water-to-sample ratio of $28.69 \mathrm{~mL} / \mathrm{g}$.

The aim of the present work is the identification of the optimum extraction method of rosemary leaves in order to obtain an extract that combined high total phenolic content and antioxidant activity. To that end, a comparison of two extraction methods, the solidliquid conventional extraction (CEM) and the microwave-assisted extraction (MAE), were performed. Hydroethanolic solutions containing different ethanol/water ratios were used, and the optimum conditions were identified. Subsequently, the enzyme-assisted extraction (EAE) was thoroughly studied using five different commercial enzyme formulations, three different enzyme types, in different concentrations, varying the time and temperature of the process. Finally, the implementation of EAE was evaluated as a pretreatment process to the conventional extraction.

\section{Materials and Methods}

\subsection{Raw Material}

Fresh rosemary (Rosmarinus officinalis L.) leaves were collected in September 2019 from the campus of the National Technical University of Athens in Greece. The raw material was washed, air-dried for 6 days in a dark, well-ventilated room, and then ground using a blender. 


\subsection{Chemicals}

All chemicals were of analytical grade and were used without further purification. Ethanol (absolute grade) and DPPH were purchased from Sigma-Aldrich while the FolinCiocalteu reagent and gallic acid from Merck Millipore. In all cases, distilled water was used.

\subsection{Enzyme Formulations}

The commercial enzymes used were Alcalase 2.4L FG (a serine endoprotease), Cellic CTec2 (cellulase complex that contains cellulases, B-glucosidases, and hemicellulase), Viscozyme L (multi-enzyme complex containing a wide range of carbohydrases, including arabinanase, cellulase, $\beta$-glucanase, hemicellulase, and xylanase), Cellic HTec2 (an endoxylanase) and Bioprep 3000L (an alkaline pectinase) and were kindly provided by Novozymes A/S (Bagsværd, Denmark).

Enzyme activities were determined as described previously [23,24]. Enzyme activities are presented in Table 1.

Table 1. Activities (U/mL of enzyme preparation) in the commercial enzyme preparations.

\begin{tabular}{cc}
\hline Enzyme Preparation & Activity (Units/mL of Enzyme Preparation) \\
\hline Alcalase 2.4L FG & 2.8 \\
Cellic CTec2 & 221 \\
Viscozyme L & 121 \\
Cellic HTec2 & 9685 \\
Bioprep 3000 & 417 \\
\hline
\end{tabular}

\subsection{Extraction of Antioxidant Compounds}

\subsubsection{Solid-Liquid Conventional Extraction (CEM)}

A total of $0.5 \mathrm{~g}$ of air-dried rosemary was subjected to extraction at room temperature for $24 \mathrm{~h}$, using $10 \mathrm{~mL}$ of hydroethanolic solution (ethanol/water 95:5 v/v, 70:30 v/v, 50:50 $v / v$ ). The sample was then centrifuged at $3000 \mathrm{rpm}$, the precipitate was discarded, and the supernatant was freeze-dried using a Christ Freeze dryer Alpha RVC.

\subsubsection{Microwave-Assisted Extraction (MAE)}

The same quantities were also used for the MAE. The samples were extracted at $50{ }^{\circ} \mathrm{C}$ for $1 \mathrm{~h}$ using a Milestone Start D Microwave Digestion System.

\subsubsection{Enzyme-Assisted Extraction (EAE)}

A total of $25 \mathrm{mg}$ of enzyme formulation were added in $20 \mathrm{~mL}$ (unless stated otherwise) of specifically selected buffer containing $1 \mathrm{~g}$ of air-dried rosemary ( $2.5 \mathrm{~g}$ enzyme $/ 100 \mathrm{~g}$ raw material). The buffers used were a disodium phosphate-citric acid buffer at $\mathrm{pH} 5$ and a Tris- $\mathrm{HCl}$ buffer at $\mathrm{pH} 8$, depending on the type of enzyme. The sample was stirred for $2 \mathrm{~h}$ at $50^{\circ} \mathrm{C}$, and a volume of $1 \mathrm{~mL}$ sample was sampled every hour. The final extract was obtained by centrifugation and freeze-drying.

\subsubsection{Enzyme Pretreatment}

The dried rosemary leaves sample was subjected to enzymatic treatment for 1 or $5 \mathrm{~h}$, as described above. The mixture was centrifuged, followed by extraction of the precipitate with ethanol/water 50:50 v/v for $24 \mathrm{~h}$.

\subsection{Determination of the Antioxidant Activity}

The free radical scavenging activity (antioxidant activity) was determined using the DPPH (2,2-diphenyl-1-picrylhydrazyl) method. Briefly, $3.9 \mathrm{~mL}$ of DPPH $(\mathrm{C}=0.025 \mathrm{~g} / \mathrm{L})$ ethanol solution was added to $0.1 \mathrm{~mL}$ of a $10 \mathrm{mg} / \mathrm{mL}$ extract solution appropriately diluted in ethanol. The samples were stored in the dark before the measurement. The absorbance 
at $515 \mathrm{~nm}$ was recorded after $30 \mathrm{~min}$. The inhibitory concentration $\left(\mathrm{IC}_{50}\right)$ of the DPPH radicals obtained by the extracts was compared to that of gallic acid [25].

\subsection{Total Phenolic Content}

The total phenolic content (TPC) was determined using the Folic-Ciocalteu assay. More specifically, $0.1 \mathrm{~mL}$ of rosemary extract of concentration $10 \mathrm{mg} / \mathrm{mL}$ (in triplicate), $6 \mathrm{~mL}$ purified water, and $0.5 \mathrm{~mL}$ Folic-Ciocalteau reagent were swirled to mix and allowed to stand for $5 \mathrm{~min}$ at room temperature. Subsequently, $1.5 \mathrm{~mL}$ of a solution of saturated sodium carbonate was added. Purified water was added up to a final volume of $10 \mathrm{~mL}$. Solutions of multiple concentrations were mixed and allowed to stand for $1 \mathrm{~h}$ at room temperature before measurement of the absorbance at $755 \mathrm{~nm}$, using UV-Vis spectrophotometer. The results were expressed as gallic acid equivalents [26].

\subsection{Extraction Kinetics}

In order to determine the extraction rate constant of total phenolics, the second-order rate law was applied $[17,18]$ :

$$
\frac{d C_{t}}{d t}=k \cdot\left(C_{e}-C_{t}\right)^{2}
$$

where:

$k$ is the second-order extraction rate constant expressed in $\mathrm{g}^{-1}$ rosemary $\cdot \mathrm{mg}^{-1} \cdot \mathrm{min}^{-1}$.

$C_{e}$ is the extraction capacity (the equilibrium concentration of total phenolics in the extraction solution) expressed in $\mathrm{mg} \cdot \mathrm{g}^{-1}$ rosemary.

$C_{t}$ is the concentration of total phenolics at a given extraction time, expressed in $\mathrm{mg} \cdot \mathrm{g}^{-1}$ rosemary.

The integrated rate law for a second-order extraction, under the boundary conditions $t=0$ to $t$ and $C_{t}=0$ to $C_{t}$, can be written as in Equation (2):

$$
C_{t}=\frac{C_{e}^{2} \cdot k \cdot t}{1+C_{e} \cdot k \cdot t}
$$

The initial extraction rate $\mathrm{h}\left(\mathrm{mg} \cdot \mathrm{g}^{-1}\right.$ rosemary $\left.\cdot \mathrm{min}^{-1}\right)$, as $C_{t} / t$ tends to zero, is deduced by Equation (3):

$$
h=k \cdot C_{e}^{2}
$$

The $h, C_{\mathrm{e}}$, and $k$ were determined by Equation (2) by non-linear regression using SigmaPlot (SysStat Software, Inc., San Jose, CA, USA).

\section{Results and Discussion}

\subsection{Conventional Extraction Method (CEM) and Microwave-Assisted Extraction (MAE)}

Table 2 shows the ability of the extracts to scavenge the stable free radical DPPH and the total phenolic content (TPC) of the extracts obtained by CEM and MAE using different ethanol/water solutions. It is apparent that the ethanol/water ratio affects the concentration of the extracted phenolic compounds as well as the antioxidant activity of the extract.

The extract obtained from CEM at room temperature, using ethanol/water 95:5 $v / v$, showed the highest antioxidant activity $\left(\mathrm{IC}_{50}=12.1 \mu \mathrm{g} / \mathrm{mL}\right)$ but one of the lowest TPC $\left(4.1 \mathrm{mg}_{\mathrm{GAE}} / \mathrm{g}_{\text {rosemary }}\right)$ among all the extracts. An interesting observation is that during CEM, the TPC increases with increasing the water content in the extracting solvent: the highest TPC $\left(11.1 \mathrm{mg}_{\mathrm{GAE}} / \mathrm{g}_{\text {rosemary }}\right)$ was obtained in ethanol/water 50:50 $\mathrm{v} / \mathrm{v}$. This result is in agreement with the recent work from Psarrou et al. [13], who observed the same trend for the extraction of phenolics from rosemary distillation residue. Tsakona et al. [27] also reported that the use of hydroethanolic solvent leads to the extraction of both hydrophilic and lipophilic phenols from Mediterranean plants. 
Table 2. The effect of the extraction method and solvent on the antioxidant activity and the total phenolic content recovered from dried rosemary leaves.

\begin{tabular}{ccc}
\hline $\begin{array}{c}\text { Extraction Method- } \\
\text { Hydroethanolic Solvent }\end{array}$ & $\begin{array}{c}\text { DPPH Radical Scavenging Ability } \\
\text { IC }_{\mathbf{5 0}}(\boldsymbol{\mu g} / \mathbf{m L})\end{array}$ & $\begin{array}{c}\text { TPC } \\
\left.\mathbf{( m g A E}_{\text {GAE }} / \mathbf{g}_{\text {rosemary }}\right)\end{array}$ \\
\hline CEM-ethanol/water 95:5 $v / v$ & $12.1 \pm 0.5$ & $4.1 \pm 0.4$ \\
CEM-ethanol/water 70:30 v/v & $16.8 \pm 1.2$ & $8.5 \pm 0.5$ \\
CEM-ethanol/water 50:50 v/v & $20.6 \pm 1.1$ & $11.1 \pm 0.4$ \\
MAE-ethanol/water 95:5 v/v & $24.0 \pm 1.1$ & $3.0 \pm 0.3$ \\
MAE-ethanol/water 70:30 v/v & $19.3 \pm 0.9$ & $7.0 \pm 0.6$ \\
MAE-ethanol/water 50:50 v/v & $19.2 \pm 0.7$ & $8.9 \pm 0.6$ \\
Gallic acid & $6.1 \pm 0.3$ & - \\
\hline
\end{tabular}

Another point worth noting is that, in the case of CEM, the DPPH radical scavenging ability decreased with increasing TPC. This might seem strange as one could expect the opposite trend, considering that phenolic compounds are known for their strong radical scavenging ability. However, this result can be explained by the fact that there are some non-phenolic compounds that can react with the Folin-Ciocalteau reagent (such as glucose and citric acid) but which cannot interact with DPPH $[28,29]$. Analogous observations have been made by Terpinc et al. [30], who studied the TPC and antioxidant activity of the extracts of fat-free residues of five different oilseeds.

As far as MAE is concerned, the difference in dielectric properties of the solvents commonly used in MAE is of great significance. More precisely, the mixture of water and ethanol has a higher dielectric constant $\left(\varepsilon^{\prime}\right)$ and good heating efficacy $(\tan \delta)$, increasing the exerted pressure on the cell wall of the plants, causing its rupture and releasing its bioactive compounds. The results obtained from the MAE showed that by increasing the amount of water in the solvent mixture, the TPC and the DPPH radical scavenging ability both increase. This is an indication that MAE potentially leads to the extraction preferably of phenolics which are strong DPPH scavengers. MAE using ethanol/water 50:50 v/v provided an extract with TPC and DPPH radical scavenging ability values analogous to the extract obtained by CEM using ethanol/water 70:30 $v / v$, in a significantly shorter extraction time ( $1 \mathrm{~h}$ for MAE and $24 \mathrm{~h}$ for CEM).

\subsection{Enzyme-Assisted Extraction (EAE)}

The total phenolic content profile of the EAE obtained extracts showed that, for all enzymes, there was a burst release of phenols at the first hour of the process, but after five hours, their concentration in the extract remained stable. The use of proteolytic (Alcalase 2.4L FG) and pectinolytic (Bioprep 3000L) enzyme resulted in the release of approximately $18 \%$ more phenolic compounds compared to cellulolytic and hemicellulolytic ones.

The kinetics curves of total phenolic content (TPC) with extraction times (Figure 1) for the five different enzyme preparations were nonlinearly fitted to Equation (2), using SigmaPlot software. The extraction capacity, $C_{\mathrm{e}}$, the initial extraction rate, $\mathrm{h}$, the extraction rate constant, $k$, and the coefficient of determination, $R^{2}$, for the five different enzymes used are presented in Table 3. The second-order model fitted well the experimental results due to the obtained high coefficient of determination. This confirmed that there are two main stages during phenolics extraction from rosemary: the first stage involves the dissolution of soluble constituents near particle surfaces into the solvent and is characterized by a rapid extraction rate; The second stage involves the mass transfer of soluble constituents from the internal material into the solvent by the diffusion process and is characterized by a slow extraction rate $[17,18]$. The kinetic constants for both cellulolytic enzyme preparations (Cellic Ctec2 and Viscozyme L) were found almost similar, while Cellic Htec2 (the hemicellulolytic enzyme preparation) had a slightly higher initial extraction rate $(h)$. Furthermore, initial extraction rates $(h)$ as well as second-order extraction rate constants $(k)$ of the above enzymes were higher compared to pectinase (Bioprep 3000L) and protease (Alcalase $2.4 \mathrm{~L}$ FG). On the other hand, pectinase and protease had higher $C_{e}$ values (Table 3 ). 


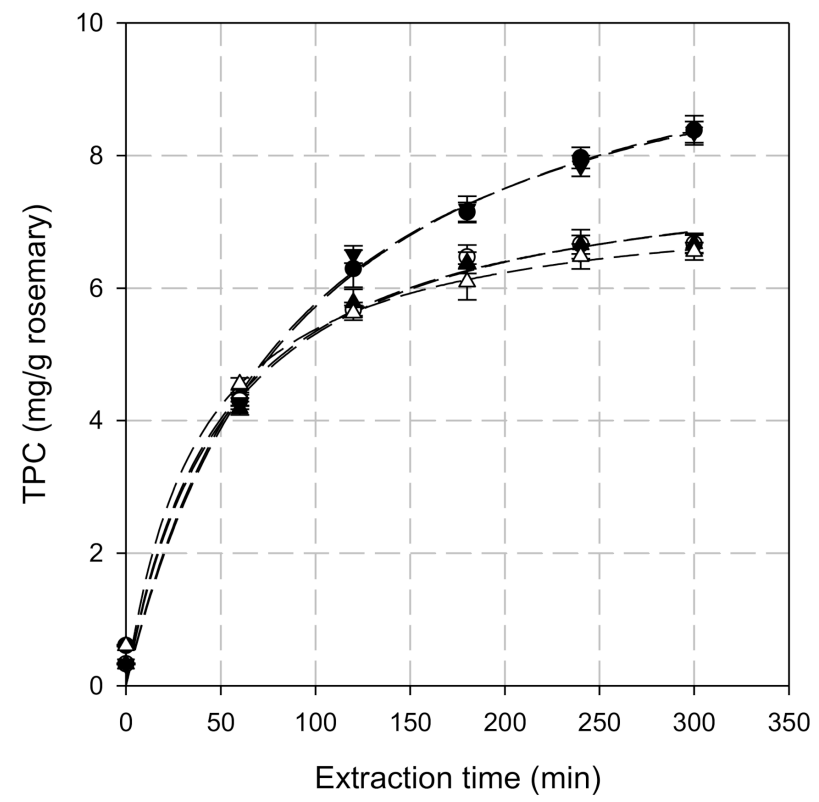

Figure 1. Effect of enzymatic extraction time on TPC. Symbols: $(\bullet)$ Alcalase 2.4L FG, $($ ) Cellic CTec2, $(\boldsymbol{\Delta})$ Viscozyme L, $(\triangle)$ Cellic HTec2, ( $\mathbf{v})$ Bioprep 3000L. Dashed lines are the non-linear fitting curves (Equation (2)).

Table 3. Kinetic parameters of EAE.

\begin{tabular}{|c|c|c|c|}
\hline Enzyme & $\begin{array}{l}\mathrm{C}_{\mathrm{e}}\left(\mathrm{mg} \mathrm{g}^{-1}\right. \\
\text { Rosemary) }\end{array}$ & $\begin{array}{c}\mathrm{k}\left(\mathrm{g}^{-1} \underset{\operatorname{Rosemary} \cdot \mathrm{mg}^{-1}}{\left.\min ^{-1}\right)}\right. \\
\end{array}$ & $\begin{array}{c}\mathrm{h}\left(\mathrm{mg} \cdot \mathrm{g}^{-1}\right. \\
\left.\text { Rosemary } \cdot \min ^{-1}\right)\end{array}$ \\
\hline Cellic Htec2 & 7.4 & $3.6 \times 10^{-3}$ & $2.0 \times 10^{-1}$ \\
\hline \multicolumn{4}{|c|}{$\left(\mathrm{R}^{2}=0.991, p<0.0001\right)$} \\
\hline Cellic Ctec2 & 8.0 & $2.6 \times 10^{-3}$ & $1.6 \times 10^{-1}$ \\
\hline \multicolumn{4}{|c|}{$\left(\mathrm{R}^{2}=0.997, p<0.0001\right)$} \\
\hline Viscozyme L & 8.0 & $2.4 \times 10^{-3}$ & $1.6 \times 10^{-1}$ \\
\hline \multicolumn{4}{|c|}{$\left(\mathrm{R}^{2}=0.996, p<0.0001\right)$} \\
\hline Bioprep 3000L & 10.9 & $1.1 \times 10^{-3}$ & $1.2 \times 10^{-1}$ \\
\hline \multicolumn{4}{|c|}{$\left(\mathrm{R}^{2}=0.996, p<0.0001\right)$} \\
\hline Alcalase 2.4L FG & 10.7 & $1.1 \times 10^{-3}$ & $1.2 \times 10^{-1}$ \\
\hline \multicolumn{4}{|c|}{$\left(\mathrm{R}^{2}=0.995, p<0.0001\right)$} \\
\hline
\end{tabular}

Pectin constitutes the middle lamella, and its function is to bind the cells together, while it is also part of the primary cell wall matrix and binds water. Degradation of the pectin may lead to a significant increase of the phenolics release by reducing the barrier effect, reported as one of the dominant resistances for mass transfer. This could act against (a) the penetration of the enzymes specifically attacking the polysaccharide-protein-phenol structure linkages and (b) the migration of the phenols released from both the carbohydrate structure of the primary and secondary cell wall and from other parts in the cytoplasm domain-vacuolar and/or nuclear phenols [31]. On the other hand, proteases were added to catalyze the breaking down of the structural proteins stiffening the polysaccharide domain in the primary and secondary cell wall. If weakened, this structure may become more porous and allow a higher penetration of solvent and enzymes, easing the solvent contact and mass transfer of the phenols from the interior of the plant matrix.

The antioxidant activity of the extracts was measured at $1 \mathrm{~h}$ and $5 \mathrm{~h}$ in order to conclude on the optimal EAE conditions that will be used as pretreatment (Table 4). 
Table 4. Effect of the enzyme type on the antioxidant activity during enzymatic extraction.

\begin{tabular}{ccc}
\hline & \multicolumn{2}{c}{ Extraction Time } \\
\cline { 2 - 3 } Enzyme & $\boldsymbol{t}=\mathbf{1} \mathbf{~ h}$ & $\boldsymbol{t}=\mathbf{5} \mathbf{h}$ \\
\cline { 2 - 3 } & \multicolumn{2}{c}{ DPPH Radical Scavenging Ability } \\
IC $_{\mathbf{5 0}}(\boldsymbol{\mu g} / \mathbf{m L})$ \\
\hline Alcalase 2.4L FG & $32.1 \pm 3.4$ & $18.9 \pm 0.9$ \\
Cellic CTec2 & $37.9 \pm 2.5$ & $28.3 \pm 1.1$ \\
Viscozyme L & $46.0 \pm 1.4$ & $27.2 \pm 1.3$ \\
Cellic HTec2 & $31.1 \pm 1.4$ & $27.6 \pm 1.8$ \\
Bioprep 3000L & $33.6 \pm 2.9$ & $13.2 \pm 1.4$ \\
\hline
\end{tabular}

The pectinolytic enzyme (Bioprep 3000L) led to the extract with the highest antioxidant activity, and therefore it was used for further experimentation.

The possibility of using distilled water instead of aqueous buffer for the EAE with Bioprep 3000L was investigated. To that end, the extraction was repeated with distilled water, and the TPC values were recorded for $24 \mathrm{~h}$ (Figure 2).

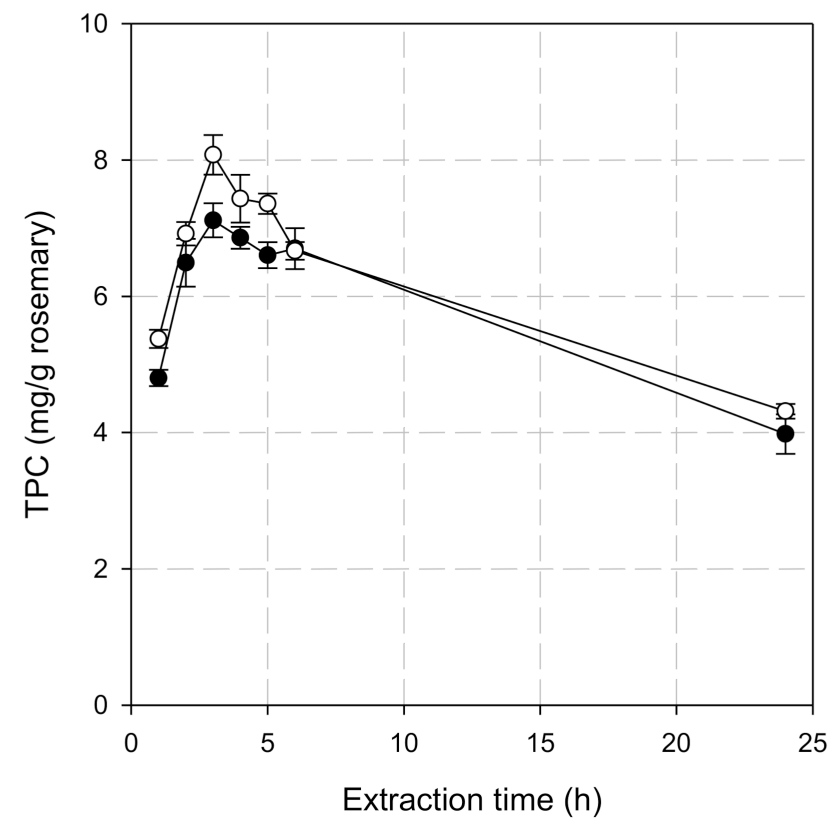

Figure 2. TPC (mgGAE/g rosemary) values for a $24 \mathrm{~h}$ enzyme-assisted extraction in water using (•) $2.5 \%$ or $(\bigcirc) 5.0 \%(w / w)$ of Bioprep 3000L.

As it can be observed from Figure 2, there was a burst release of phenols for the first $3 \mathrm{~h}$ of the extraction. Further increase in incubation time resulted in a progressive reduction in TPC. Long enzyme treatment time, 24 versus $3 \mathrm{~h}$, had a significantly negative effect on the phenol recovery. According to Meyer et al. [32], this negative effect of time indicates that phenols were probably degraded during the long enzyme treatment.

Moreover, for the first $6 \mathrm{~h}$ of extraction with pectinase, the TPC was not significantly higher when aqueous buffer was used. Therefore, distilled water was used for a 24-h extraction of rosemary with twice the amount of the enzyme in order to investigate the influence of the enzyme loading. Increasing the amount of enzyme did indeed slightly increase the TPC value of the extracts.

\subsection{EAE as a Pretreatment Method of CEM}

The next step was to investigate the pretreatment of the rosemary leaves with pectinase for $1 \mathrm{~h}$ or $5 \mathrm{~h}$ followed by conventional extraction using ethanol/water 50:50 for $24 \mathrm{~h}$. 
The TPC and DPPH radical scavenging ability of the extracts obtained by this combined methodology is presented in Table 5 .

Table 5. TPC (mgGAE/g) and DPPH radical scavenging ability $\left[\mathrm{IC}_{50}(\mu \mathrm{g} / \mathrm{mL})\right]$ of the extracts obtained by enzyme pretreatment followed by conventional extraction.

\begin{tabular}{ccc}
\hline Extraction Method & $\begin{array}{c}\text { DPPH Radical Scavenging Ability } \\
\mathbf{I C}_{\mathbf{5 0}}(\boldsymbol{\mu g} / \mathbf{m L})\end{array}$ & $\begin{array}{c}\text { TPC } \\
\left(\mathbf{m g}_{\mathrm{GAE}} / \mathbf{g}_{\text {rosemary }}\right)\end{array}$ \\
\hline $\begin{array}{c}\text { 1 h enzymatic pretreatment }+24 \mathrm{~h} \\
\text { CEM }\end{array}$ & $14.3 \pm 0.8$ & $15.2 \pm 0.3$ \\
5 h enzymatic pretreatment $+24 \mathrm{~h}$ & $17.2 \pm 1.2$ & $13.0 \pm 0.5$ \\
CEM & & \\
\hline
\end{tabular}

The data of Table 5 indicated that the highest recovery was achieved for 1-h enzymatic pretreatment followed by $24 \mathrm{~h}$ conventional extraction. It was also observed that, despite the fact that the $5 \mathrm{~h}$ pretreatment step solely resulted in higher antioxidant activity (Table 4), the combination of the two aforementioned methods was more efficient for 1-h enzyme pretreatment. Comparing the results between the different types of extraction, the EAE presented the highest values for both antioxidant activity and TPC. This can be assigned to the degradation and disruption of the cell wall matrix, as pectinase depolymerizes cell-wall polysaccharides and hydrolyzes the glycosidic linkages between phenolic compounds and cell wall polymers. Consequently, not only the structure of the cell wall can be weakened and broken down, whereby intracellular materials are more exposed to extraction, but also the solubility of the target substances can be improved [33]. In order to determine the optimum time for the combined extraction method, $1 \mathrm{~h}$ pretreatment with pectinase, followed by 1 to $24 \mathrm{~h}$ CEM was conducted. Figure 3 shows the differences in TPC values of the different extraction times.

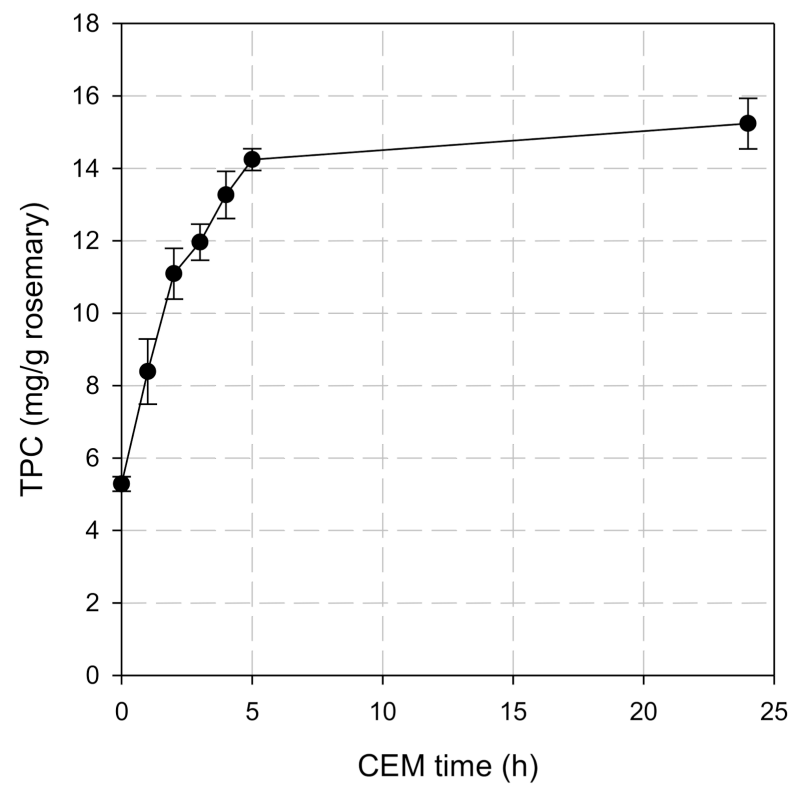

Figure 3. The effect of extraction time on the TPC $\left(\mathrm{mg}_{\mathrm{GAE}} / \mathrm{g}_{\text {rosemary }}\right)(\bullet)$.

Figure 4 depicts the curves of total phenolics with extraction times for CEM and combined EAE and CEM. The curves, as above, were nonlinearly fitted to Equation (2), using SigmaPlot software. The extraction capacity, $\mathrm{Ce}$, the initial extraction rate, $\mathrm{h}$, the extraction rate constant, $\mathrm{k}$, and the coefficient of determination, $\mathrm{R}^{2}$, for the two different methods used are presented in Table 6. As above, the second-order model fitted well the experimental results owing to the obtained high coefficient of determination. 


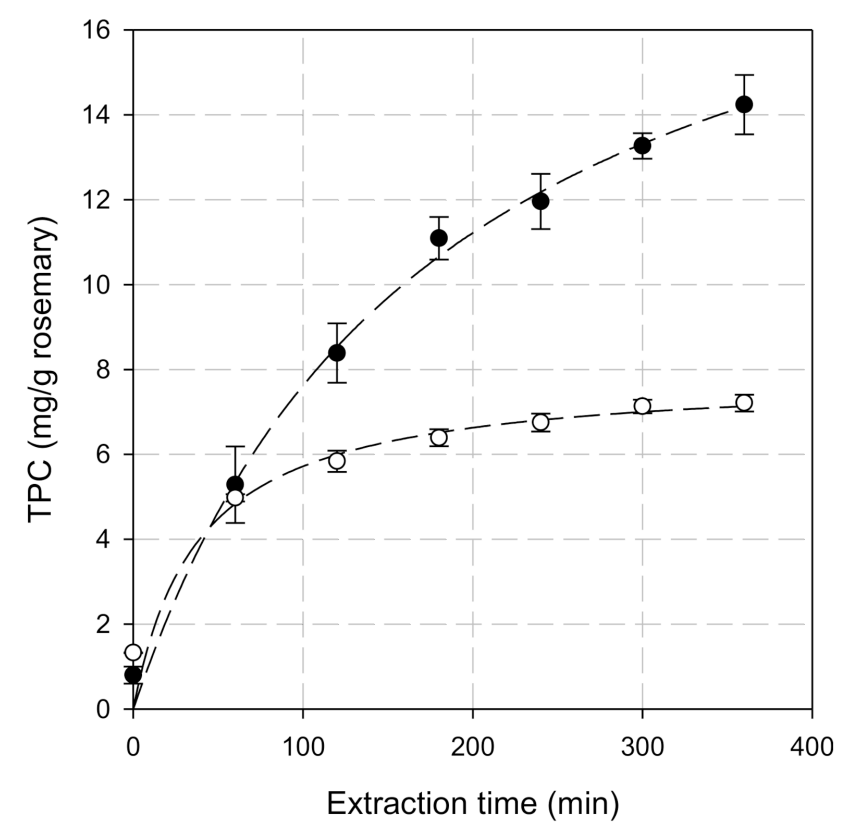

Figure 4. Effect of extraction time on TPC during $(\bigcirc)$ conventional extraction $(50 \% v / v$ ethanol) and $(\bullet)$ EAE + CEM. Dashed lines are the non-linear fitting curves (Equation (2)).

Table 6. Kinetic parameters of conventional extraction and EAE + CEM.

\begin{tabular}{|c|c|c|c|}
\hline Extraction Method & $\begin{array}{l}\mathrm{C}_{\mathrm{e}}\left(\mathrm{mg} \mathrm{g} \mathrm{g}^{-1}\right. \\
\text { Rosemary) }\end{array}$ & $\begin{array}{c}\text { k (g-1 Rosemary } \cdot \mathrm{mg}^{-1} \\
\left.\min ^{-1}\right)\end{array}$ & $\begin{array}{c}\mathrm{h}\left(\mathrm{mg} \cdot \mathrm{g}^{-1}\right. \\
\left.\text { Rosemary } \cdot \min ^{-1}\right)\end{array}$ \\
\hline CEM $50 \% v / v$ ethanol & 7.9 & $3.3 \times 10^{-3}$ & $2.1 \times 10^{-1}$ \\
\hline \multicolumn{4}{|c|}{$\left(\mathrm{R}^{2}=0.998, p<0.0001\right)$} \\
\hline $\mathrm{EAE}+\mathrm{CEM}$ & 21.2 & $2.6 \times 10^{-4}$ & $1.2 \times 10^{-1}$ \\
\hline \multicolumn{4}{|c|}{$\left(\mathrm{R}^{2}=0.998, p<0.0001\right)$} \\
\hline
\end{tabular}

The results showed that the $h, k$, and $C_{\mathrm{e}}$ were affected by the type of extraction method applied (Table 5). Combined EAE and CEM exhibited approximately 3.0 times higher Ce value compared to conventional ones. Therefore, a combination of EAE and CEM can improve the extraction of antioxidants from rosemary leaves.

EAE has several advantages regarding the extraction of bioactive compounds; however, it encounters potential commercial and technical shortcomings. The cost of enzymes could be comparatively expensive if processing with a high ratio of enzyme to substrate in large scale or industrial-scale production. Moreover, EAE can be challenging to scale up in the industry because enzymes behave differently under different environmental conditions (such as temperature and $\mathrm{pH}$ ), and temperature and $\mathrm{pH}$ could vary inside an industrial-scale extractor $[34,35]$. On the other hand, as it is shown by the results of the present work, enzyme pretreatment of rosemary leaves can offer extracts of better quality regarding phenolic content and antioxidant activity; thus, the cost of the enzyme can be compensated to a certain extent if an industrial application is considered.

\section{Conclusions}

Conventional extraction (CEM), as well as microwave-assisted extraction (MAE) of dried rosemary leaves, were performed, and the extracts were evaluated for their total phenolic content and DPPH radical scavenging ability. The water content of the hydroethanolic solvent seemed to play a critical role in the phenolic components extracted from rosemary. A higher TPC was not accompanied by a higher antioxidant activity when the latter was evaluated by the DPPH assay, probably because of the ability of non-phenolic compounds to provide a positive reaction with the Folin-Ciocalteau reagent. Microwave-assisted 
extraction seemed to favor the selective extraction of phenolic compounds from rosemary; thus, in this case, the extract with the higher TPC showed the best antioxidant activity.

Enzymatic assisted extraction (EAE) as a pretreatment method to a solid-liquid conventional extraction (CEM) is a promising process for the efficient extraction of phenolic phytochemicals from dried rosemary leaves. The extraction of phenolic compounds was found to depend on various parameters, including ethanol/water ratio, enzyme type, enzyme over raw material ratio, and extraction time. The pretreatment of rosemary leaves with pectinolytic enzymes for $1 \mathrm{~h}$ hydrolyzed the cell wall polysaccharides, thus significantly enhancing the phenolic yield obtained from the subsequent hydroethanolic conventional extraction. Application of an enzyme complex consisting mainly of pectinases followed by conventional extraction with ethanol/water 1:1 $v / v$ increased the extraction efficiency by at least $30 \%$.

In the case of rosemary leaves, EAE in combination with CEM was able to achieve extracts of better quality as compared to the extracts obtained only from CEM. This advantage can compensate, to a certain extent, for the cost when scale-up is the goal, and this greener approach can be considered as a useful complement to conventional extraction for obtaining high added-value extracts.

Author Contributions: Conceptualization, D.M. and A.D.; Data curation, A.R.N.P., L.P.-T. and T.L.; Investigation, A.R.N.P. and L.P.-T.; Methodology, A.R.N.P., L.P.-T. and T.L.; Project administration, D.M. and A.D.; Resources, D.M., D.K. and A.D.; Writing—original draft, A.R.N.P., L.P.-T., T.L., D.M. and D.K. All authors have read and agreed to the published version of the manuscript.

Funding: This research received no external funding.

Institutional Review Board Statement: Not applicable.

Informed Consent Statement: Not applicable.

Data Availability Statement: Not applicable.

Acknowledgments: A.R.N.P. would like to thank the General Secretariat for Research and Technology (GSRT) and the Hellenic Foundation for Research and Innovation (HFRI) for funding her PhD research. The authors would like to thank Novozymes A/S (Bagsværd, Denmark) for supplying the enzymes used in the study.

Conflicts of Interest: The authors declare no conflict of interest.

\section{References}

1. Lešnik, S.; Furlan, V.; Bren, U. Rosemary (Rosmarinus officinalis L.): Extraction techniques, analytical methods and healthpromoting biological effects. Phytochem. Rev. 2021. [CrossRef]

2. Himed-Idir, H.; Mouhoubi, K.; Siar, E.H.; Boudries, H.; Mansouri, H.; Adjeroud, N.; Madani, K.; Boulekbache-Makhlouf, L. Effect of rosemary (Rosmarinus officinalis L.) supplementation on fresh cheese: Physicochemical properties, antioxidant potential, and sensory attributes. J. Food Process. Preserv. 2021, 45, e15057. [CrossRef]

3. Teixeira, J.S.; Repková, L.; Gänzle, M.G.; McMullen, L.M. Effect of pressure, reconstituted RTE meat microbiota, and antimicrobials on survival and post-pressure growth of Listeria monocytogenes on ham. Front. Microbiol. 2018, 9, 1979. [CrossRef] [PubMed]

4. Nakagawa, S.; Hillebrand, G.G.; Nunez, G. Rosmarinus officinalis L. (rosemary) extracts containing carnosic acid and carnosolare potent quorum sensing inhibitors of Staphylococcus Aureus virulence. Antibiotics 2020, 9, 149. [CrossRef] [PubMed]

5. Pérez-Sánchez, A.; Barrajón-Catalán, E.; Ruiz-Torres, V.; Agulló-Chazarra, L.; Herranz-López, M.; Valdés, A.; Cifuentes, A.; Micol, V. Rosemary (Rosmarinus officinalis) extract causes ROS-induced necrotic cell death and inhibits tumor growth in vivo. Sci. Rep. 2019, 9, 1-11.

6. Shen, Y.; Han, J.; Zheng, X.; Ai, B.; Yang, Y.; Xiao, D.; Zheng, L.; Sheng, Z. Rosemary leaf extract inhibits glycation, breast cancer proliferation, and diabetes risks. Appl. Sci. 2020, 10, 2249. [CrossRef]

7. Makaremi, S.; Ganji, A.; Ghazavi, A.; Mosayebi, G. Inhibition of tumor growth in CT-26 colorectal cancer-bearing mice with alcoholic extracts of Curcuma longa and Rosmarinus officinalis. Gene Rep. 2021, 22, 101006. [CrossRef]

8. Guo, Y.; Xie, J.; Li, X.; Yuan, Y.; Zhang, L.; Hu, W.; Luo, H.; Yu, H.; Zhang, R. Antidepressant effects of rosemary extracts associate with anti-inflammatory effect and rebalance of gut microbiota. Front. Pharmacol. 2018, 9, 1126. [CrossRef]

9. Rahbardar, M.G.; Amin, B.; Mehri, S.; Mirnajafi-Zadeh, S.J.; Hosseinzadeh, H. Anti-inflammatory effects of ethanolic extract of Rosmarinus officinalis L. and rosmarinic acid in a rat model of neuropathic pain. Biomed. Pharmacother. 2017, 86, 441-449. [CrossRef] 
10. Munekata, P.E.; Alcántara, C.; Žugčić, T.; Abdelkebir, R.; Collado, M.C.; García-Pérez, J.V.; Jambrak, A.R.; Gavahian, M.; Barba, F.J.; Lorenzo, J.M. Impact of ultrasound-assisted extraction and solvent composition on bioactive compounds and in vitro biological activities of thyme and rosemary. Food Res. Int. 2020, 134, 109242. [CrossRef]

11. Sik, B.; Hanczné, E.L.; Kapcsándi, V.; Ajtony, Z. Conventional and nonconventional extraction techniques for optimal extraction processes of rosmarinic acid from six Lamiaceae plants as determined by HPLC-DAD measurement. J. Pharm. Biomed. Anal. 2020, 184, 113173. [CrossRef]

12. Rodríguez-Rojo, S.; Visentin, A.; Maestri, D.; Cocero, M.J. Assisted extraction of rosemary antioxidants with green solvents. J. Food Eng. 2012, 109, 98-103. [CrossRef]

13. Psarrou, I.; Oreopoulou, A.; Tsimogiannis, D.; Oreopoulou, V. Extraction Kinetics of Phenolic Antioxidants from the Hydro Distillation Residues of Rosemary and Effect of Pretreatment and Extraction Parameters. Molecules 2020, 25, 4520. [CrossRef]

14. Barbieri, J.B.; Goltz, C.; Cavalheiro, F.B.; Toci, A.T.; Igarashi-Mafra, L.; Mafra, M.R. Deep eutectic solvents applied in the extraction and stabilization of rosemary (Rosmarinus officinalis L.) phenolic compounds. Ind. Crop. Prod. 2020, 144, 112049. [CrossRef]

15. Wojeicchowski, J.P.; Marques, C.; Igarashi-Mafra, L.; Coutinho, J.A.; Mafra, M.R. Extraction of phenolic compounds from rosemary using choline chloride-based Deep Eutectic Solvents. Sep. Purif. Technol. 2021, 258, 117975. [CrossRef]

16. Lefebvre, T.; Destandau, E.; Lesellier, E. Sequential extraction of carnosic acid, rosmarinic acid and pigments (carotenoids and chlorophylls) from Rosemary by online supercritical fluid extraction-supercritical fluid chromatography. J. Chromatogr. A 2021, 1639, 461709. [CrossRef]

17. Nadar, S.S.; Rao, P.; Rathod, V.K. Enzyme assisted extraction of biomolecules as an approach to novel extraction technology: A review. Food Res. Int. 2018, 108, 309-330. [CrossRef]

18. Gligor, O.; Mocan, A.; Moldovan, C.; Locatelli, M.; Crișan, G.; Ferreira, I.C. Enzyme-assisted extractions of polyphenols-A comprehensive review. Trends Food Sci. Technol. 2019, 88, 302-315. [CrossRef]

19. Song, Y.R.; Han, A.R.; Park, S.G.; Cho, C.W.; Rhee, Y.K.; Hong, H.D. Effect of enzyme-assisted extraction on the physicochemical properties and bioactive potential of lotus leaf polysaccharides. Int. J. Biol. Macromol. 2020, 153, 169-179. [CrossRef]

20. Lombardelli, C.; Liburdi, K.; Benucci, I.; Esti, M. Tailored and synergistic enzyme-assisted extraction of carotenoid-containing chromoplasts from tomatoes. Food Bioprod. Process. 2020, 121, 43-53. [CrossRef]

21. Neta, I.M.R.; de Castro, R.J.S. Enzyme-assisted extraction of biocomponents of lentils (Lens culinaris L.): Effect of process parameters on the recovery of compounds with antioxidant properties. Biocatal. Biotransformation 2020, 38, 15-23. [CrossRef]

22. Nguyen, H.C.; Nguyen, H.N.T.; Huang, M.Y.; Lin, K.H.; Pham, D.C.; Tran, Y.B.; Su, C.H. Optimization of aqueous enzymeassisted extraction of rosmarinic acid from rosemary (Rosmarinus officinalis L.) leaves and the antioxidant activity of the extract. $J$. Food Process. Preserv. 2020, 45, e15221.

23. Kalantzi, S.; Kekos, D.; Mamma, D. Bioscouring of cotton fabrics by multienzyme combinations: Application of Box-Behnken design and desirability function. Cellulose 2019, 26, 2771-2790. [CrossRef]

24. Paschos, T.; Louloudi, A.; Papayannakos, N.; Kekos, D.; Mamma, D. Potential of barley straw for high titer bioethanol production applying prehydrolysis and simultaneous saccharification and fermentation at high solid loading. Biofuels 2020. [CrossRef]

25. Chatzidaki, M.; Kostopoulou, I.; Kourtesi, C.; Pitterou, I.; Avramiotis, S.; Xenakis, A.; Detsi, A. $\beta$-Cyclodextrin as carrier of novel antioxidants: A structural and efficacy study. Colloids Surf. A Physicochem. Eng. Asp. 2020,603, 125262. [CrossRef]

26. Shannon, E.; Abu-Ghannam, N. Enzymatic extraction of fucoxanthin from brown seaweeds. Int. J. Food Sci. Technol. 2018, 53, 2195-2204. [CrossRef]

27. Tsakona, S.; Galanakis, C.M.; Gekas, V. Hydro-ethanolic mixtures for the recovery of phenols from Mediterranean plant materials. Food Bioprocess. Technol. 2012, 5, 1384-1393. [CrossRef]

28. Magalhães, L.M.; Segundo, M.A.; Reis, S.; Lima, J.L.; Rangel, A.O. Automatic method for the determination of Folin-Ciocalteu reducing capacity in food products. J. Agric. Food Chem. 2006, 54, 5241-5246. [CrossRef] [PubMed]

29. Velioglu, Y.; Mazza, G.; Gao, L.; Oomah, B.D. Antioxidant activity and total phenolics in selected fruits, vegetables, and grain products. J. Agric. Food Chem. 1998, 46, 4113-4117. [CrossRef]

30. Terpinc, P.; Čeh, B.; Ulrih, N.P.; Abramovič, H. Studies of the correlation between antioxidant properties and the total phenolic content of different oil cake extracts. Ind. Crop. Prod. 2012, 39, 210-217. [CrossRef]

31. Pinelo, M.; Zornoza, B.; Meyer, A.S. Selective release of phenols from apple skin: Mass transfer kinetics during solvent and enzyme-assisted extraction. Sep. Purif. Technol. 2008, 63, 620-627. [CrossRef]

32. Meyer, A.S.; Jepsen, S.M.; Sørensen, N.S. Enzymatic release of antioxidants for human low-density lipoprotein from grape pomace. J. Agric. Food Chem. 1998, 46, 2439-2446. [CrossRef]

33. Ximenes, E.; Kim, Y.; Mosier, N.; Dien, B.; Ladisch, M. Inhibition of cellulases by phenols. Enzym. Microb. Technol. 2010, 46, 170-176. [CrossRef]

34. Wen, L.; Zhang, Z.; Sun, D.W.; Sivagnanam, S.P.; Tiwari, B.K. Combination of emerging technologies for the extraction of bioactive compounds. Crit. Rev. Food Sci. Nutr. 2020, 60, 1826-1841. [CrossRef]

35. Puri, M.; Sharma, D.; Barrow, C.J. Enzyme-assisted extraction of bioactives from plants. Trends Biotechnol. $2012,30,37-44$. [CrossRef] 